\title{
A CLINICAL CASE OF UNILATERAL OVARIAN DYSGERMINOMAAND PYOMETRA IN A BITCH
}

\author{
Anton Antonov ${ }^{1}$, Ivan Fasulkov ${ }^{1}$, Radostin Simeonov ${ }^{2}$ \\ ${ }^{1}$ Department of Obstetrics, Reproduction and Reproductive Disorders, \\ Faculty of Veterinary Medicine, Trakia University, 6000 Stara Zagora, Bulgaria \\ ${ }^{2}$ Department of General and Clinical Pathology, Faculty of Veterinary Medicine, \\ Trakia University, 6000 Stara Zagora, Bulgaria
}

Received 4 February 2014; Received in revised form 26 February 2014; Accepted 25 March 2014

\begin{abstract}
A clinical case of an 11-year-old bitch with unilateral ovarian dysgerminoma and pyometra is described. The owner reported purulent discharge from external genitalia, fastidious appetite and depression. Transabdominal ultrasonography of the reproductive organs showed a hypoechoic mass in the region of the left ovary $(7.18 \times 6.65 \mathrm{~cm})$ and a strongly enlarged uterine lumen full of anechoic fluid. Vaginal cytology demonstrated about $50 \%$ superficial cornfield epithelial cells and multiple neutrophils. Complete blood counts and blood biochemistry analysis indicated a significant leukocytosis and a mild anemia. Blood progesterone $(3.96 \mathrm{ng} / \mathrm{ml})$ and estradiol $(86 \mathrm{pg} / \mathrm{ml})$ were assayed. Median laparotomy revealed an enlarged uterus, substantially altered left ovary, of the size of a grapefruit. The right ovary was of normal size and structure. Tumor metastases in other organs were not seen. Histologically, diffusely located cancer cells resembling primitive germ cells, specific for dysgerminomas, were established. One year after the surgery, according to the owner the dog is vital, with normal appetite and without general condition abnormalities.
\end{abstract}

Key words: dysgerminoma, pyometra, bitch, tumors

\section{INTRODUCTION}

Ovarian dysgerminomas belong to the group of germ cell tumors, together with teratomas and teratocarcinomas $(12,18)$. Dysgerminomas are massive tumors originating from the undifferentiated ovarian epithelium $(5,8,10)$. Macroscopic size of dysgerminomas ranges from 2 to $30 \mathrm{~cm}$ (13). Histologically they are comparable to testicular seminomas, and thus also termed embryonic carcinomas and ovarian seminomas (2, 10). According to most researchers, these tumors are rarely encountered, and in dogs they account for

Corresponding author: Assist. Prof. Ivan Fasulkov, PhD

E-mail address: i.fasulkov@gmail.com

Present address: Department of Obstetrics, Reproduction

and Reproductive Disorders

Faculty of Veterinary Medicine, Trakia University,

6000 Stara Zagora, Bulgaria

Copyright: (C) 2014 Antonov A. This is an open-access article published under the terms of the Creative Commons Attribution License which permits unrestricted use, distribution, and reproduction in any medium, provided the original author and source are credited.

Competing Interests: The authors have declared that no competing interests exist.

Available Online First: 26 April 2014

http://dx.doi.org/10.14432/j.macvetrev.2014.04.013
6-20\% of ovarian neoplasms $(3,7,15)$. Regardless of the similar histological findings in benign and malignant dysgerminomas, McEntee (12) affirms that $10-20 \%$ of canine dysgerminomas are malignant. Metastases of this cancer have been observed in lymph nodes, brain, liver, kidneys, adrenal glands, omentum, serous intestinal tract surface, lungs and retroperitoneal space $(3,6,13)$. The age of the dogs with ovarian dysgerminoma ranges between 2 and 15 years $(1,6,13,14)$, but a breed predilection has not been established. There are single reports for simultaneous ovarian dysgerminoma and pyometra in the bitch, but to our best knowledge, there is no detailed description of ultrasound findings and blood hormonal profile, namely serum progesterone and estradiol. The clinical case presented here describes a unilateral ovarian dysgerminoma with a pyometra in a bitch. The emphasis was placed on clinical signs, ultrasound findings, vaginal cytology, haematology and blood biochemistry data, serum progesterone and estradiol levels and histological findings confirming the diagnosis. 


\section{CASE DESCRIPTION}

\section{Patient history and physical examination}

In February 2013, a female German Shepherd dog, 11 years of age, body weight $40 \mathrm{~kg}$, was referred to the Small Animal Clinic of the Faculty of Veterinary Medicine, Trakia University - Stara Zagora. The owner reported a one-week history of a purulent discharge from the external genitalia, fastidious appetite and depression. According to owner observation, the last estrus was 6 months ago, the dog had given birth six times, without complications. Until the referral to the clinic, the dog had been treated with procain benzylpenicillin and dihydrostreptomycin sulphate (Intramicine, Ceva Sante Animale, France) for 5 days and two subcutaneous aglepristone (Alizin, Virbac, France) injections, but in the owner's view - without effect. The rectal body temperature was $38.2^{\circ} \mathrm{C}$, the heart rate $86 / \mathrm{min}$, the respiratory rate $25 / \mathrm{min}$, and visible mucous coats - pink-red. The abdomen was slightly enlarged, soft and not painful on palpation. The vulva was oedematous, with purulent discharge.

\section{Ultrasound imaging of reproductive organs}

Ultrasonography was done with the ultrasound apparatus DC-6 Vet (Mindray, China), equipped with 6.5 MHz convex transducer using the transabdominal approach. The findings were documented on a Mitsubishi P91E (Tokyo, Japan) printer. During the examination, caudally to the kidney, a large well differentiated hypoechoic mass $7.18 \times 6.65 \mathrm{~cm}$ in size was visualized in the region of the left ovary, with clearly distinguished several small cavities (Fig.1-A). The examination of the uterus showed an extremely enlarged anechoic fluid-filled lumen and a thickened wall of the uterus (Fig.1-B)
Vaginal cytology

A vaginal swab was collected and a cytovaginal smear was prepared and stained (Hemacolor, Merck). Light microscopy (magnification $40 \times$ ) of the smear showed about 50\% superficial cornified epithelial cells and a lot of segmented neutrophils (Fig. 2).

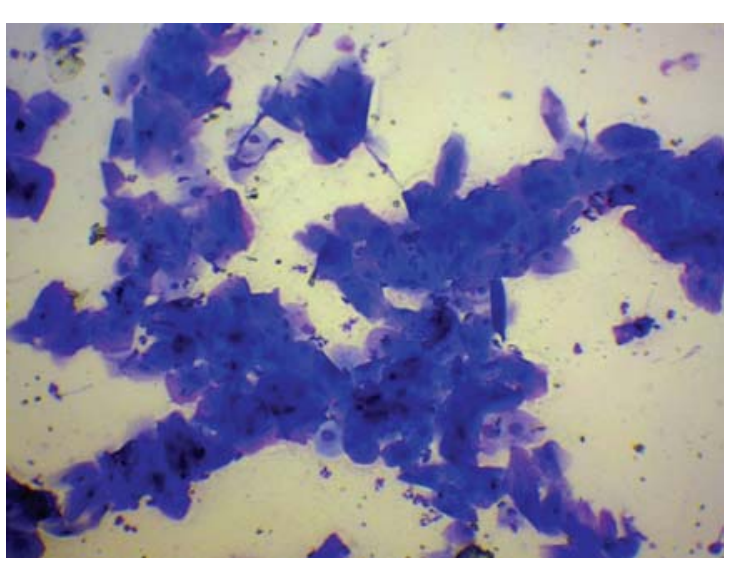

Figure 2. Vaginal cytology - presence of superficial cornified cells and neutrophils

Complete blood counts and blood biochemical analysis

Complete blood cell counts were assayed on an automated haematological analyser BC-2800 Vet (Mindray, China), and blood biochemical parameters - on an automated biochemical analyser BS 120 (Mindray, China). Blood laboratory analysis (Table 1) showed a marked leukocytosis and mild anaemia.

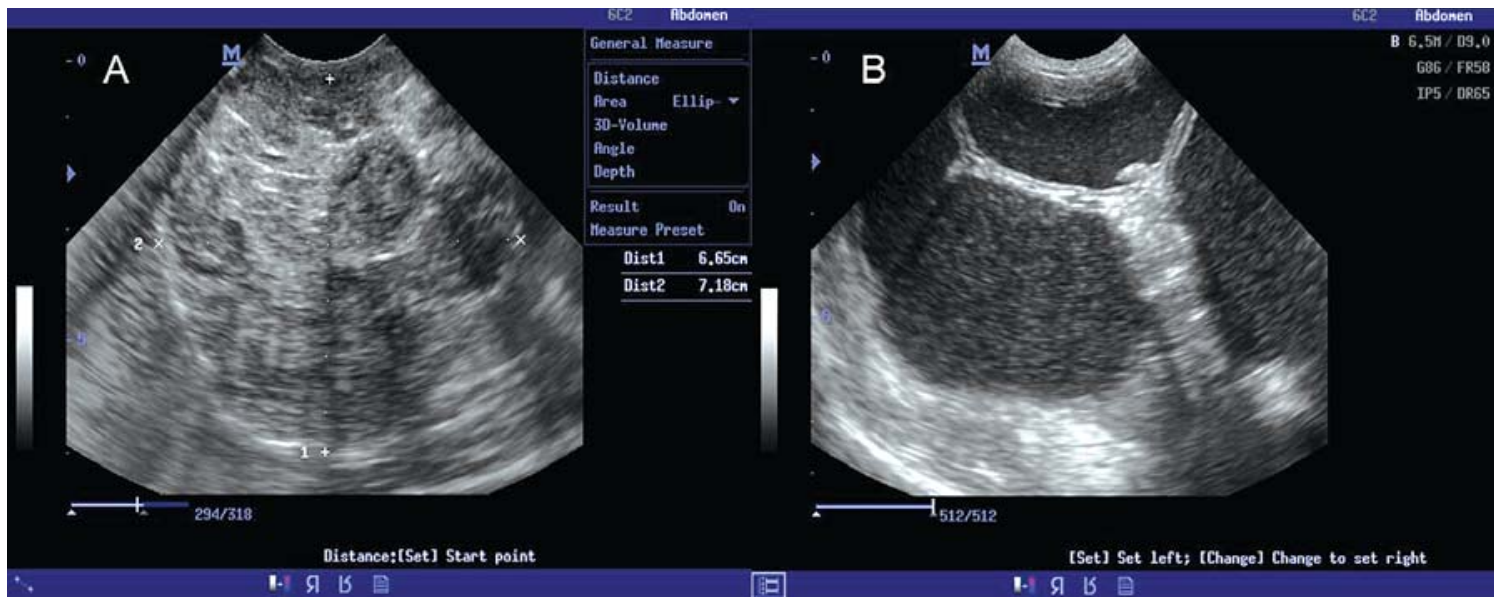

Figure 1. Ultrasound scan of the left ovary (A) and the uterus (B): A - hypoechoic mass with several cavities inside; $\mathrm{B}$ - enlarged uterine lumen with anechoic fluid 
A clinical case of unilateral ovarian dysgerminoma and pyometra in a bitch

Table 1. Patient's hematological and blood biochemistry analysis results

\begin{tabular}{|c|c|c|c|c|c|}
\hline Hematology & Result & $\begin{array}{l}\text { Reference } \\
\text { values* }\end{array}$ & Biochemistry & Result & $\begin{array}{l}\text { Reference } \\
\text { values** }\end{array}$ \\
\hline $\begin{array}{l}\text { HGB } \\
(\mathrm{g} / \mathrm{l})\end{array}$ & 91 & $120-180$ & $\begin{array}{c}\text { AP } \\
(\mathrm{U} / 1)\end{array}$ & 136 & $20-156$ \\
\hline $\begin{array}{l}\text { HCT } \\
(\%)\end{array}$ & 23.9 & $37-55$ & $\begin{array}{l}\text { Glucose } \\
(\mathrm{mmol} / \mathrm{l})\end{array}$ & 5.58 & $3.61-6.55$ \\
\hline $\begin{array}{l}\mathrm{RBC} \\
\left(\mathrm{x} 10^{12} / 1\right)\end{array}$ & 3.99 & $5.5-8.5$ & $\begin{array}{l}\text { AST } \\
(\mathrm{U} / 1)\end{array}$ & 29 & $23-66$ \\
\hline $\begin{array}{l}\text { WBC } \\
\left(x \quad 10^{9} / 1\right)\end{array}$ & 38.4 & $6.0-17.0$ & $\begin{array}{l}\text { ALT } \\
(\mathrm{U} / \mathrm{l})\end{array}$ & 24 & $21-102$ \\
\hline $\begin{array}{l}\text { PLT } \\
(\mathrm{x} \mathrm{10} / 1)\end{array}$ & 407 & $200-500$ & $\begin{array}{c}\text { Urea } \\
(\mathrm{mmol} / \mathrm{l})\end{array}$ & 2.9 & $1.67-3.33$ \\
\hline $\begin{array}{l}\mathrm{MCV} \\
\text { (fl) }\end{array}$ & 59.9 & $60-77$ & $\begin{array}{l}\text { Creatinine } \\
(\mu \mathrm{mol} / 1)\end{array}$ & 63.0 & $44.2-132.6$ \\
\hline
\end{tabular}

Legend: HGB - hemoglobin; RBC - red blood cells; WBC - white blood cells; PLT - platelets; MCV - mean corpuscular volume; AP - alkaline phosphatase; AST - aspartate aminotransferase; ALT - alanine aminotransferase. * Weiss and Wardrop (17); ** Kaneko et al. (11)

\section{Blood hormonal profile}

Blood serum progesterone was assayed using a Progesterone ELISA kit (Dialab, Austria), and estradiol - with Estradiol ELISA kit (Human, Germany). The tests use a competitive sandwich ELISA for quantitation of progesterone and estradiol in biological fluids. The sample optical densities were calculated from respective standard curves in $\mathrm{pg} / \mathrm{ml}$ (for estradiol) and $\mathrm{ng} / \mathrm{ml}$ (for progesterone). Thus, the blood progesterone of the patient was $3.96 \mathrm{ng} / \mathrm{ml}$, and the blood estradiol $-86 \mathrm{pg} / \mathrm{ml}$.

\section{Surgery}

After aseptic preparation of the abdominal region, the bitch was premedicated with 0.04 $\mathrm{mg} / \mathrm{kg}$ atropine sulfate (Atropinum sulfuricum; Sopharma; Bulgaria), applied subcutaneously. Fifteen minutes later, anaesthesia was induced by intravenous administration of $0.4 \mathrm{mg} / \mathrm{kg}$ diazepam (Diazepam; Sopharma; Bulgaria) and $10 \mathrm{mg} / \mathrm{kg}$ ketamine (Anaket 10\%; Richter Pharma Ag; Austria). After endotracheal intubation, the anaesthesia was maintained with isoflurane (Terrell ${ }^{\mathrm{TM}}$; Minrad Inc.; USA). The median laparotomy was performed. After opening the peritoneum, an enlarged uterus and a considerably altered left ovary, the size of a grapefruit, were observed (Fig. 3), while the right ovary had normal structure and size. There were no tumor metastases in the other abdominal organs. Complete ovariohysterectomy was then performed. Specimens for histology were collected from the excised tumor mass. The abdominal cavity was flushed twice with sterile saline and closed with cross stitch pattern using USP $1 / 0$ polyglycolic acid absorbable sutures (Marlin; Catgut GmbH; Markneukirchen), and the skin was sutured with simple interrupted non-absorbable sutures USP 0 (Vitalon; Dr Hammer \& Co. GmbH; Hamburg). Postoperative treatment included antibiotic - $8.75 \mathrm{mg} / \mathrm{kg}$ amoxicillin clavulanic acid (Synulox RTU; Zoetis; USA) intramuscularly for 5 days and a NSAID - $2 \mathrm{mg} / \mathrm{kg}$ ketoprofen (Ketofen 1\%; Merial; France), intramuscularly for 3 days. An Elizabethan collar was placed. Skin sutures were removed after 10 days. The post-operative examination showed that the patient's recovery was good.

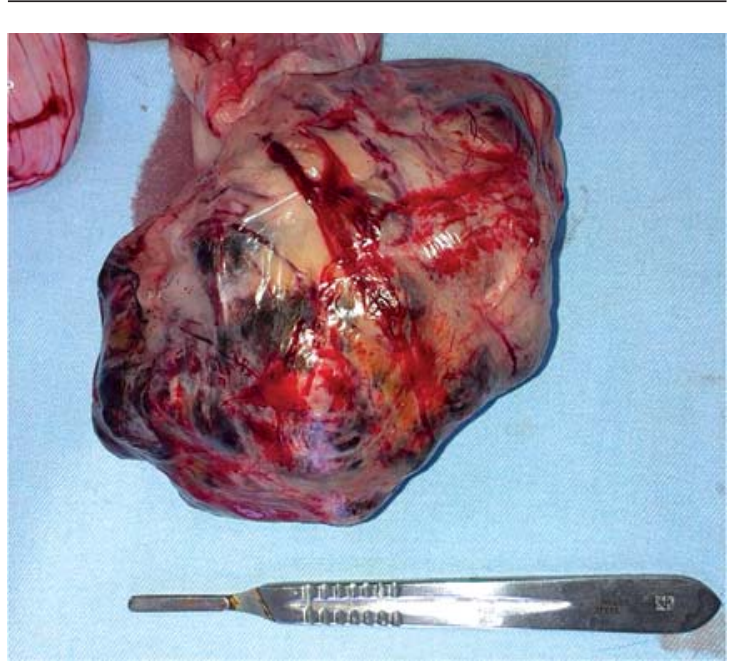

Figure 3. Macroscopic appearance of the tumor mass 


\section{Histological examination}

The specimens for histological examination were fixed in $10 \%$ neutral formalin. Samples were cut on a paraffin microtome with $4 \mu \mathrm{m}$ thickness. The cross sections were processed using the standard histological techniques (4) and stained with haematoxylin/eosin. Neoplastic cells were diffusely located (Fig. 4) and resembled primitive germ cells. Their nuclei were vesicular and prominent nucleoli were frequently seen. Mitotic figures were observed in some areas. In regression zones, polynuclear cells and lymphocytes were observed. The tumor stroma was sparse (Fig. 5).

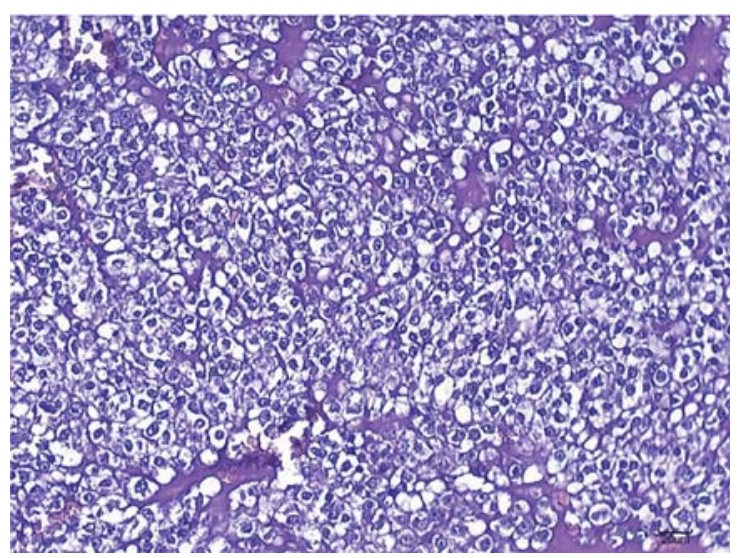

Figure 4. Dysgerminoma - diffuse of neoplastic cells localization

\section{DISCUSSION}

Ovarian dysgerminoma complicated with pyometra is a rare condition in female dogs. Jackson et al. (9) believe that hormone production by the tumor is the predisposing factor for pyometra development. In our patient, clinical signs of pyometra were most indicative, as also reported by others $(3,7)$. Doubts regarding the presence of neoplastic ovarian formation were raised only after the diagnostic ultrasound. In support of this, a number of researchers affirm that some germ cell tumors could be asymptomatic and without disturbing the ovarian function $(5,10)$. Several cases of ovarian dysgerminoma in normally cycling bitches have been described $(2,5)$. Very often, dysgerminomas were found accidentally in laparotomies performed on other occasions, for instance pyometra (9).

In a dog with ovarian dysgerminoma, Novotny et al. (13) observed the ovary by ultrasound imaging as a structure with multiple cavities, 2 to $4 \mathrm{~mm}$ in diameter. We have also noticed several cavities within the tumor mass. The size of the formation, as established by ultrasonography, was about $7 \mathrm{~cm}$, a 182 size similar to reports by Park et al. (14) and Rolim et al. (15). The cornified epithelial cells observed on the cytovaginal smear correlated to high blood estradiol concentration $(86 \mathrm{pg} / \mathrm{ml})$. In a bitch with ovarian dysgerminoma, Novotny et al. (13) established about $40 \%$ cornified superficial cells. The pyometra developed in our patient was accompanied by a blood progesterone level of $3.96 \mathrm{ng} / \mathrm{ml}$. Depending on the sexual cycle stage (diestrus, anoestrus) in bitches with spontaneous pyometra, Ververidis et al. (16) reported blood estradiol between $3.7-23 \mathrm{pg} / \mathrm{ml}$, and blood progesterone - within the range $0.36-32 \mathrm{ng} / \mathrm{ml}$.

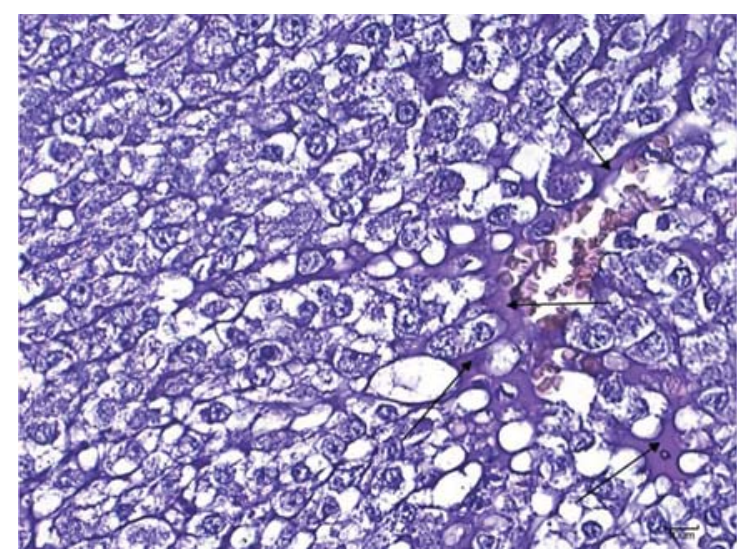

Figure 5. Polyhedral neoplastic cells. Vesicular nuclei and the scarce stroma of the tumor (arrows) are clearly visible

All researchers describing this pathological condition consider the surgical removal of ovaries and the uterus to be the proper therapeutical choice $(8,9,13,15)$.

Ovarian dysgerminoma was confirmed after the histological examination. Features specific for this tumor are the presence of rather large neoplastic cells of polyhedral shape, resembling the primitive germ cells $(1,7,15)$. Immunohistochemistry could be an alternative for diagnosing this neoplasm (14, 15).

The prognosis of ovarian dysgerminoma largely depends on the presence or lack of metastases in internal organs. Despite the poor prognosis, Novotny et al. (13) reported that 20 months after the operation of an ovarian dysgerminoma with retroperitoneal metastases present, the bitch was still alive. In the presently reported case, 1 year after operation the dog has preserved its vitality, good appetite and normal general health status according to the owner. 


\section{REFERENCES}

1. Andrews, E.J., Stookey, J.L., Helland, D.R., Slaughter, L.J. (1974). A histopathological study of canine and feline ovarian dysgerminomas. Can J Comp Med. 38: 85-89.

PMid:4272962; PMCid:PMC1319972

2. Buergelt, C. (1968). Dysgerminomas in two dogs. J Am Vet Med Assoc. 153: 553-555. PMid:5691153

3. Dehner, L.P., Norris, H.J., Garner, F.M., Taylor, H.B. (1970). Comparative pathology of ovarian neoplasms. III. Germ cell tumors of canine, bovine, feline, rodent and human species. J Comp Pathol. 80: 299-310.

PMid: 5449975

4. Diakov, L., Lozanov, L., Stoikov, D. (1989). Manual for veterinary pathohistology. Sofia: Zemizdat. PMid:2697957

5. Dillberger, J.E., Altman, N.H. (1987). A canine ovarian germ cell tumor with extraembryonic differentiation. Vet Pathol. 24: 96-98. PMid:3029938

6. Fernández, T., Díez-Bru, N., Rios, A., Gómez, L., Pumarola, M. (2001). Intracranial metastases from an ovarian dysgerminoma in a 2-yearold dog. J Am Anim Hosp Assoc. 37: 553-556. PMid:11716030

7. Greenlee, P.G., Patnaik, A.K. (1985). Canine ovarian tumors of germ cell origin. Vet Pathol. 22: 117-122. PMid:2984828

8. Ishmael, J. (1970). Dysgerminoma of the ovary in a bitch. J Small Anim Pract. 11: 697-701. http://dx.doi.org/10.1111/j.1748-5827.1970.tb07051.x PMid:5533241

9. Jackson, M.L., Mills, J.H.L., Fowler, J.D. (1985). Ovarian dysgerminoma in a bitch. Can Vet J. 26: 285-287.

PMid:17422574; PMCid:PMC1680110
10. Johnston, SD, Kustritz, M.V.R., Olson, P.N.S. (2001). Canine and feline theriogenology. Philadelphia: Saunders, pp. 203-205.

11. Kaneko, J.J., Harvey, J.W., Bruss, M. (2008). Clinical biochemistry of domestic animals, $6^{\text {th }}$ ed. Philadelphia: Saunders.

http://dx.doi.org/10.1016/B978-0-12-370491-7.00031-3

12. McEntee, M.C. (2002). Reproductive oncology. Clin Tech Small Anim Pract. 17: 133-149. http://dx.doi.org/10.1053/svms.2002.34642 PMid:12476817

13. Novotny, R., Vitasek, R., Bartoskova, A. (2011). Ovarian dysgerminoma with retroperitoneal metastases in a bitch: a case report. Vet Med-Czech, 56: $140-144$.

14. Park, J.K., Goo, M.J., Hong, I.H., Ki, M.R., Han, J.Y., Jeong, K.S. (2009). Immunohistochemistry diagnosis of an ovarian dysgerminoma in one bitch. Reprod Dom Anim. 44: 855-858.

http://dx.doi.org/10.1111/j.1439-0531.2008.01135.x PMid:18992107

15. Rolim, V.M., Pinto, T.M., de Almeida Lopes, L.M., Sonne, L., de Oliveira, E.C., de Almeida, P.R., de Castro Beck, C.A., Driemeier, D. (2010). Bilateral dysgerminoma and cystic endometrial hyperplasia with pyometra in a bitch. Acta Sci Vet. 38: 337-340.

16. Ververidis, H.N., Boscos, C.M., Stefanakis, A., Saratsis, P., Stamou, A.I., Krambovitis, E. (2004). Serum estradiol-17 $\beta$, progesterone and respective uterine cytosol receptor concentrations in bitches with spontaneous pyometra. Theriogenology, 62: 614-623.

http://dx.doi.org/10.1016/j.theriogenology.2003.11.011 PMid:15226016

17. Weiss, D.J., Wardrop, K.J. (2010). Schalm's veterinary hematology, $6^{\text {th }}$ ed. Iowa: Blackwell Publishing. 